УДК 7.071.1

17.00.09 Теория и история искусства

АКВАРЕЛИСТ ОЛЕГ ИГОРЕВИЧ
ПОМЕРАНЦЕВ (1949-2012) КАК
ПРОДОЛЖАТЕЛЬ ТРАДИЦИЙ
РЕАЛИСТИЧЕСОГО ИСКУССТВА.
ХУДОЖЕСТВЕННЫЙ ОБРАЗ ПОСЁЛКА
КИРИЛЛОВСКОЕ В АКВАРЕЛЬНЫХ И
ГРАФИЧЕСКИХ РАБОТАХ МАСТЕРА

Мартынова Анастасия Геннадьевна аспирант кафедры культурологии и искусства Ленинградский государственный университет имени А.С. Пушкина, Пушкин-Санкт-Петербург, Poсcuя, MartynovaNastjia@mail.ru

В статье рассказывается о петербургском самобытном художнике-акварелисте, Олеге Игоревиче Померанцеве (1949-2012). Творчество мастера неразрывно связано с русским реализмом. Художник выступает продолжателем высоких основополагающих художественных традиций реалистического искусства. Работая в пейзажном жанре, Померанцеву удалось создать более 500 картин глубоких по содержанию и смыслу. В свободное от основной профессии время, мастер разрабатывал собственные приемы акварельной техники. Все работы художника выполнены по впечатлению. Вдохновение он получал на рыбалке, в лесу, а дома, по памяти, мастер воспроизводил увиденное. Большинство работ находятся в частных коллекциях и галереях многих стран мира.

Романтичные пейзажи Олега Игоревича

Померанцева поражают прозрачностью, сложными цветовыми приемами и непередаваемой атмосферой, полной воздуха и света. Интересны и графические работы художника, выполненные карандашом на бумаге. Иногда мастер увлекался прорисовкой деталей, и работа уже не годилась под акварель. В акварельных работах Померанцев делал едва заметный рисунок карандашом. Графикой специализированно не занимался, карандашные наброски исключал, как негодные, но супруга художника их сохранила. Акварелист Олег Игоревич Померанцев неизвестен российским искусствоведам. Ввиду этого, в статье была поставлена задача впервые дать искусствоведческуюоценку творчеству художника, провести искусствоведческий анализ работ мастера из цикла «Карельский перешеек», посвященных п.Кирилловское Выборгского района. Исследование творчества Олега Померанцева профессиональными искусствоведами позволит качественно дополнить историю акварельной живописи России

Ключевые слова: ОЛЕГ ИГОРЕВИЧ ПОМЕРАНЦЕВ, КИРИЛЛОВСКОЕ, ПЕРК-ЯРВИ, ВЫБОРГ, ХУДОЖНИК, РЕАЛИЗМ, АКВАРЕЛЬ,
UDC 7.071.1

Theory and history of arts

\section{WATERCOLORIST OLEG POMERANTSEV (1949-2012) AS A SUCCESSOR OF THE TRADITIONS OF REALISTIC ART. ARTISTIC IMAGE OF THE SETTLEMENT OF KIRILLOVSKOE IN WATERCOLORS AND GRAPHIC WORKS OF THE MASTER}

\author{
Martynova Anastasia Gennadievna \\ graduate student of chair of cultural studies and arts \\ Leningrad State University named after A.S. Pushkin, \\ Pushkin, St. Petersburg, Russia, \\ MartynovaNastjia@mail.ru
}

The article tells about St. Petersburg distinctive watercolor painter, Oleg I. Pomerantsev (1949-2012). Master's career is inseparably linked with Russian realism. The artist acts as a successor of fundamental high artistic traditions of realistic art. Working in a landscape genre, Pomerantsev managed to create more than 500 paintings deep in a content and meaning. In his spare time Master developed his own techniques of watercolor art. The entire artist's works were performed under his impression. He received inspiration on fishing trips, in woods and then at home master reproduced what he saw from memory. Most of his works are in private collections and galleries all around the world. Romantic landscapes of Oleg I. Pomerantsev affect by their transparency, complex color techniques and inexpressible atmosphere, full of air and light. Complex colour manners and inexpressible atmosphere full of air and light. Graphic works by the artist, executed in pencil on paper are very interesting too. Sometimes master was fond of drawing in details, so such works were not suitable for watercolors. In his watercolor works Pomerantsev did only hardly visible pencil drawing. The artist did not specialized in graphics so he ruled out his pencil sketches as unsuitable, but the wife of the artist has kept them. Watercolorist Oleg I. Pomerantsev is unknown to Russian art-critics. In view of that, the article was tasked to give for the first time an art rating to the artist's creation, to make an art analysis of his works from the cycle "The Karelian isthmus" dedicated to the settlement of Kirillovskoe in Vyborg district. The study of creativity of Oleg Pomerantsev by professional critics will allow to expand qualitatively the history of watercolor painting of Russia

Keywords: OLEG POMERANTSEV, KIRILLOVSKOE, PERK-JARVI, VYBORG, VIIPURI, PAINTER, REALISM, WATERCOLOR, 
«...А прошел босоногий по влажной земле, по асфальту, парящему после дождя, сам промокнув до нитки, да навеселе, ног уставших, пропащей души не щзадя. А потом, если кто-то поверит твоим фиолетовым мхам, разноцветным лугам, можжевельникам, верескам не утаим, те слова, что когда-то читать по слогам начинали...»

Николай Данилин (род. в 1964г.), поэт и близкий друг художника

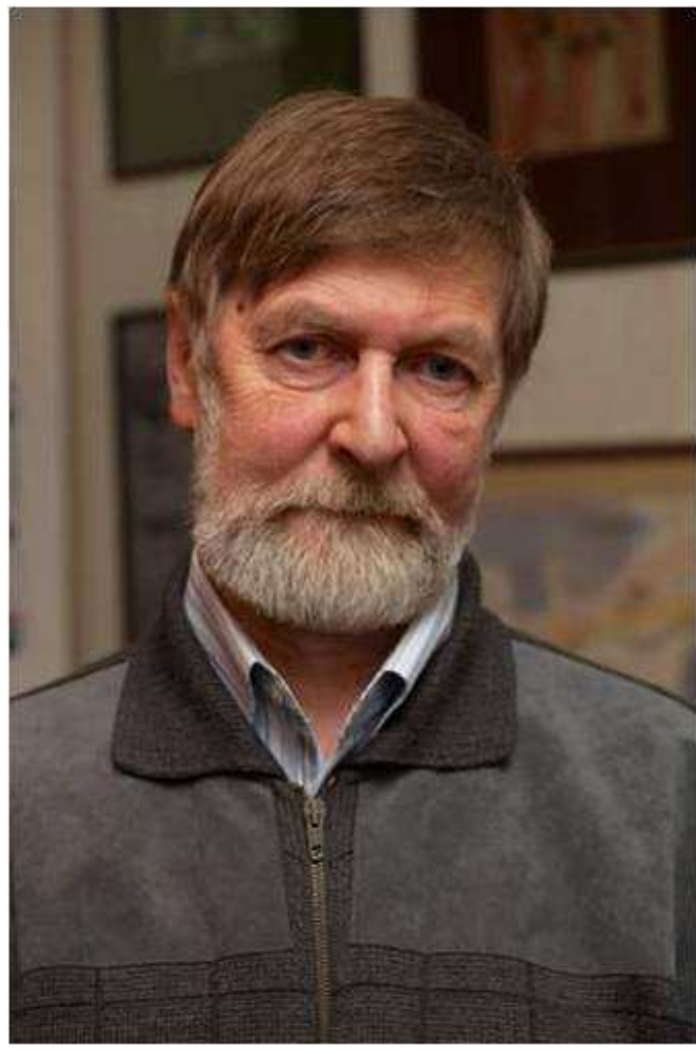

Изобр. 1 Олег Игоревич

Померанцев

(1949-2012)

Специальная подготовка акварелистов в России наметилась только к концу XX века, в связи с ростом интереса к акварельной технике. Творчество мастера акварели, Олега Померанцева, неразрывно связано с традициями реалистической школы живописи, основу которых составляет достоверность в изображении окружающего мира, где высокое мастерство исполнения блестяще сочетается с внутренней содержательностью образа.

Обращаясь к определению реализма, стоит отметить, что в рамках реализма как художественного направления целью искусства является наблюдение и объективное изображение окружающей действительности, выражение «правды жизни». Термин введён французским литературным критиком Шанфлёри в 1850-е гг. Реалистическая живопись в России была представлена передвижничеством (И. Е. Репин, В.И. Суриков, А.К. Саврасов, И.И. Шишкин, В.Е. Маковский, А.И. Куинджи, В.М. Васнецов, 
В.Д. Поленов, И.И. Левитан, И.Н. Крамской). Важным является тот факт, что не всякое внешне достоверное изображение действительности является реалистическим. Эмпирическая

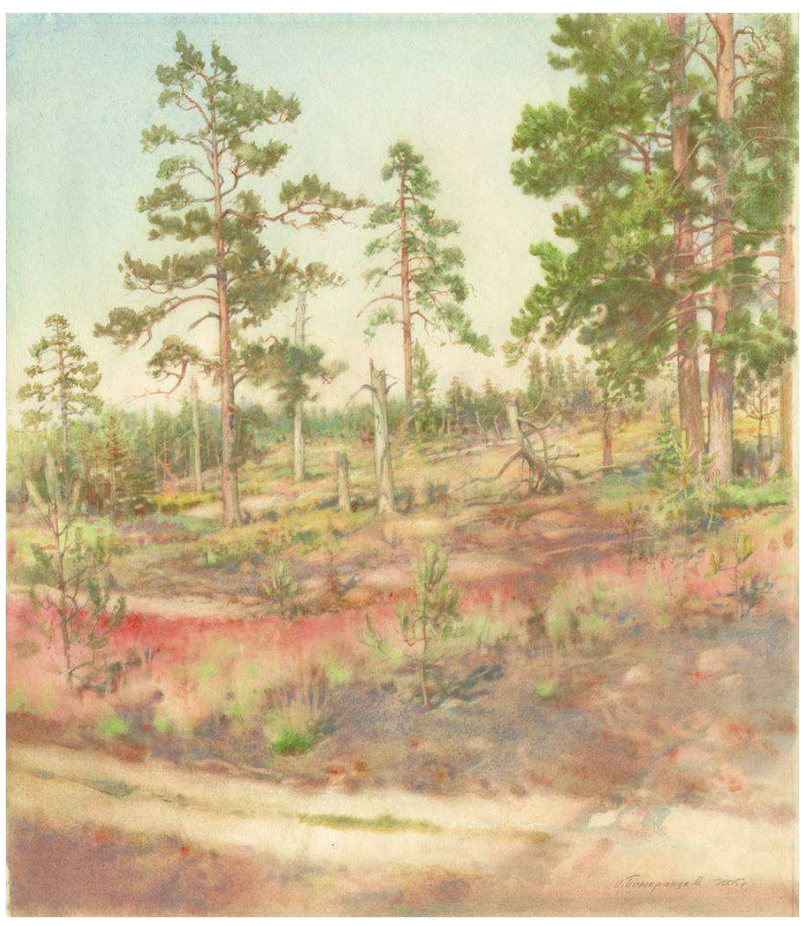

Изобр. 2 Померанцев О.И.

«Кирилловское. Полигон. Июль», 2005.

37,5 х 42 см. Бумага, акварель.

Собственность В.П. Померанцевой достоверность художественного образа обретает смысл лишь в единстве с правдивым отражением существующих сторон реального мира. В этом состоит различие между реализмом и натурализмом, создающим лишь видимую, внешнюю, а не подлинную сущностную правдивость изображений. Когда речь идет о натурализме, то это всегда частный, индивидуальный случай без какого либо обобщения [16]. Натурализм является разновидностью реализма, но при всем натурализм - это приверженность не ко всей жизни, не к действительности вообще, а преимущественно к ее наиболее стихийным, низшим проявлениям, к той стороне человеческой природы, которая роднит нас с животными. Реализм же связан с обобщением. С проблемой идеала в реалистическом искусстве тесно связан и вызывающий острые споры вопрос о соотношении реализма и романтизма. Не отрицая наличия особого романтического художественного метода, следует подчеркнуть, что черты романтизма являются отнюдь не чем-то противоположным реализму, но зачастую становятся неотъемлемым качеством реалистического произведения. Следует отметить также, что и романтизму не чужды и реалистические тенденции и черты. Показателен наглядный пример из литературы. 
Обращаясь к реалисту Бальзаку, романтик Жорж Занд так определила разницу между ним и собой: «вы берете человека таким, каким он представляется вашему взору; я же чувствую в себе призвание изображать его таким, каким хотела бы видеть» [15]. Таким образом, реализм предоставляет простор фактам. Реализм - это «поэзия фактов».

Для художника Олега Померанцева [11] пейзаж стал жанром, в котором художественное дарование смогло реализоваться полно и ярко. Ему удалось создать более 500 картин глубоких по содержанию и смыслу. В свободное от основной профессии время мастер разрабатывал собственные приемы акварельной техники.

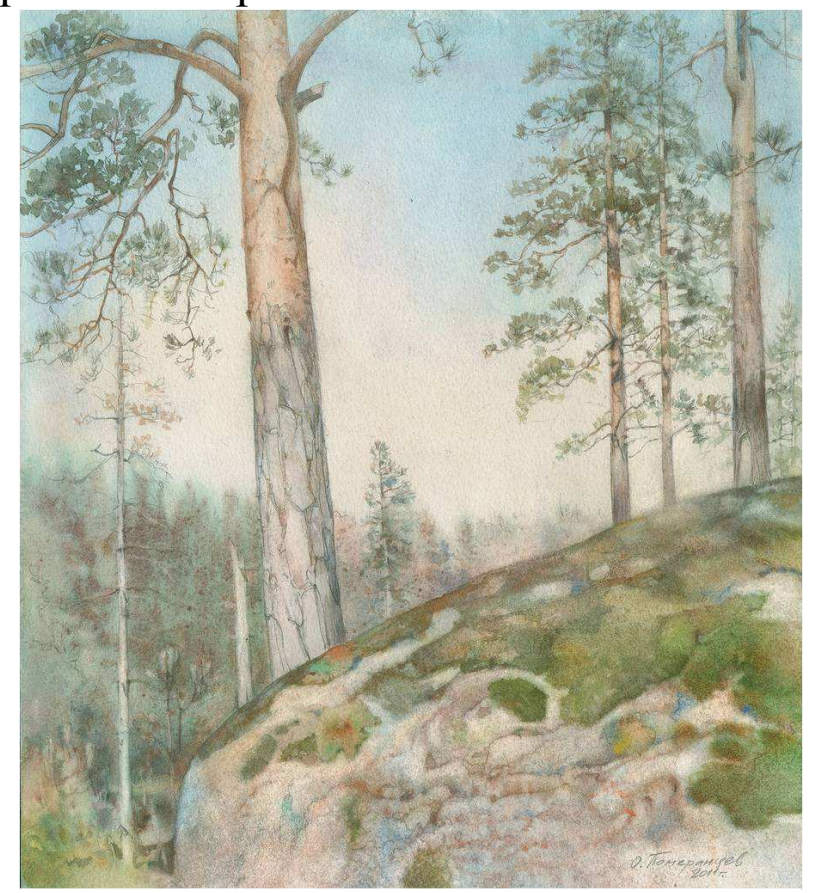

Изобр.4 Померанцев О.И. «Карельский натюрморт с камнем», 2001. 28,5 x 33 см. Бумага, акварель. Собственность В.П. Померанцевой

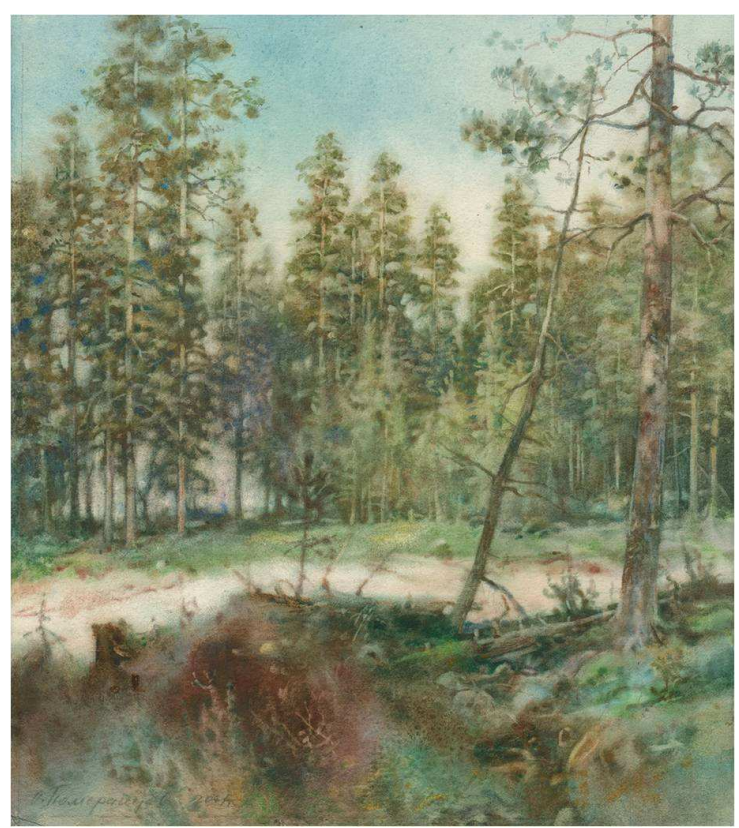

Изобр.3 Померанцев О.И. «В Кирилловском», 2001.

23 × 26 см. Бумага, акварель.

Собственность В.П. Померанцевой

\section{Остановимся подробно}

на состоянии изученности творчества художника. Несмотря на высокое мастерство работ, художник Олег Игоревич Померанцев неизвестен российским искусствоведам. Ввиду этого, перед нами была поставлена задача впервые дать искусствоведческую оценку творчеству художника, провести искусствоведческий анализ работ мастера из цикла «Карельский 
перешеек» посвященных п.Кирриловское Выборгского района и тем самым «открыть» творчество необычайного великолепного художника. В самом начале нашего исследования данной темы была опубликована

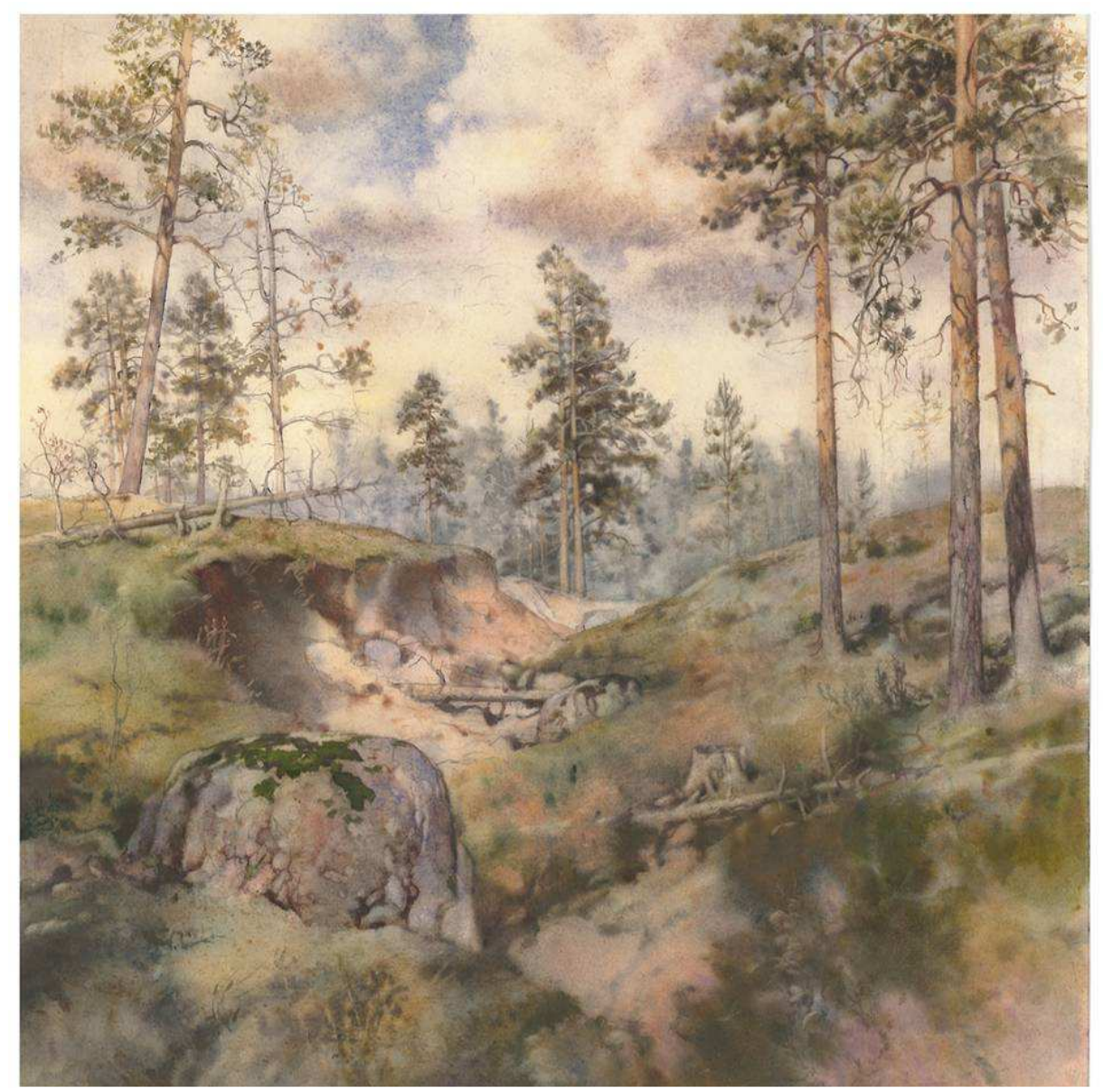

Изобр.5 Померанцев О.И. «Июль. Кирилловское», 1994.

31 х 29 см. Бумага, акварель. Собственность В.П. Померанцевой

статья «От Выборга до Порвоо» в №49 2013 г. газеты «Реквизит», которая дает краткую оценку творчества акварелиста Олега Померанцева. А в 2014 году подготовлен материал «Возрождение русских классических этнокультурных живописных традиций в творчестве художника-реалиста Олега Игоревича Померанцева (1949-2012). Природа п.Кирилловское в акварелях мастера» для $\mathrm{X}$ Всероссийской научно-практической конференции студентов, аспирантов, молодых учёных, проходящей ежегодно в Санкт-Петербургской Высшей школе народных искусств. При подготовке данной статьи была дополнительно изучена литература, ряд 
публицистических источников, видеоматериалов, интернет-ресурсов. С научной позиции, настоящая статья на сегодняшний день является наиболее исчерпывающей и своей целью ставит введение в научный оборот российского искусствоведения нового уникального художественного, историко-культурного материала.

Живопись Олега Померанцева [1] напоминает рядовому зрителю

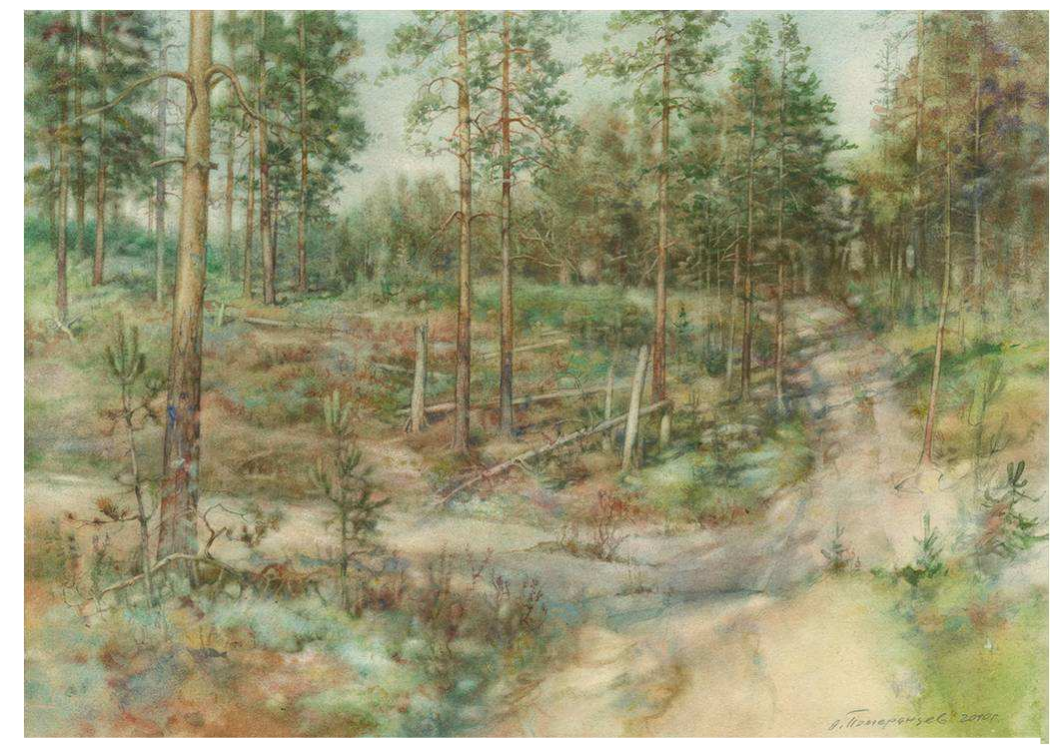

Изобр.6 Померанцев О.И. «Верхний бор. Кирилловское», 2010.

23 х 30 см. Бумага, акварель. Собственность В.П. Померанцевой

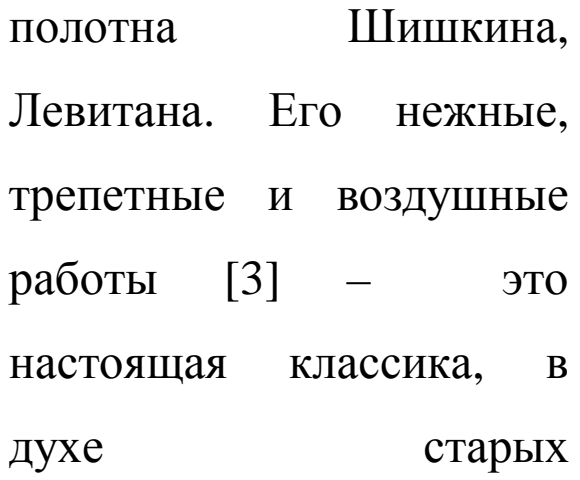

мастеров, сближающие современного зрителя с полотнами великих художников-реалистов [12].

Чтобы понять процесс становления личности художника, обратимся к его биографии. Олег Игоревич Померанцев родился 1 января 1949 года, на Урале, в городе Челябинске. После окончания школы, он поступил в Ленинградский Инженерно-Строительный институт на архитектурный факультет, а после окончания, в 1972г., по распределению получил работу в г. Череповце в качестве заместителя главного архитектора. В 1975 году Померанцев переехал в Ленинград, где работал архитектором в различных проектных институтах и персональных архитектурных мастерских. Профессиональная карьера художника началась с проектирования атомных электростанций: на счету у архитектора разработки двух крупнейших атомных станций в России. Любовь к рисованию у художника 
родилась в детстве. Померанцеву привил ее школьный учитель по рисованию, Пузанов Владимир Ефимович. С годами увлечение переросло в профессиональную сферу [10].

«Я учил его в обыкновенной школе с 6го по 8й класс и одновременно вел городскую студию. Олег учился у меня сначала в школе, а потом стал ходить в студию. Как творческого человека я заметил его в студии, поскольку в школе многие хорошо рисовали. Олег развивался как художник довольно быстро. В 8 классе он уже занял в городском конкурсе среди взрослых художников 2е место. Я брал Олега в туристические походы, где во время привала в разных красивых местах он мог писать на моем этюднике. По окончанию школы я подготовил Олега к поступлению на архитектурный факультет. Будучи архитектором он приезжал ко мне на дачу, мы писали этюды, беседовали об искусстве: художниках, направлениях, манерах письма» вспоминал о своем ученике, Олеге Померанцеве, в своем интервью Владимир Ефимович Пузанов [7].

Все работы художника были

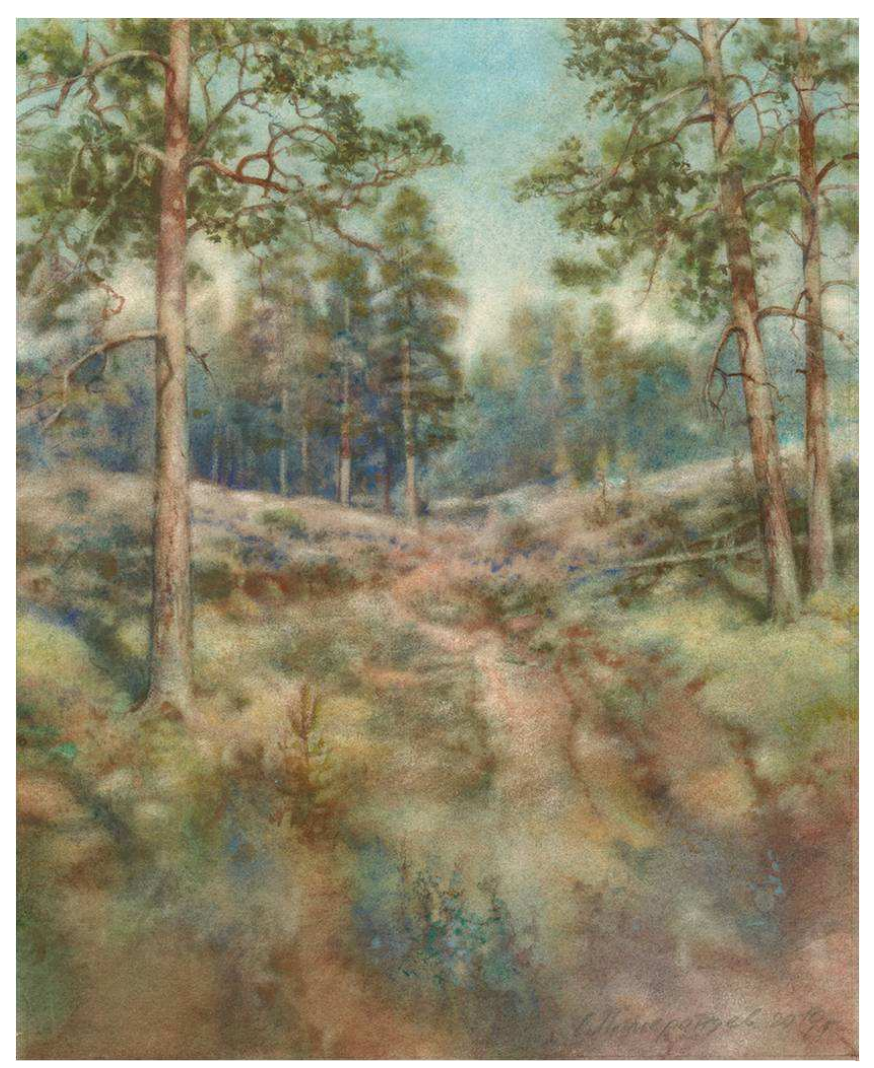

Изобр.7 Померанцев О.И. «Вересковый проход. Кирилловское», 2010. 21,5 х 26,5 см. Бумага, акварель. Собственность В.П. Померанцевой выполнены по впечатлению. Вдохновение он получал на рыбалке, в лесу, а дома, по памяти, Олег Игоревич воспроизводил увиденное. Померанцев любил природу и как человек с тонкой душевной организацией, глубоко чувствовал ее красоту. Художник создал более 500 акварелей. Большинство работ находятся в частных коллекциях и галереях многих 
стран мира. Успешные выставки состоялись в Германии $(1991,1993,1995)$ совместно с петербургскими художниками, где каждый имел свой выставочный блок. В 1997г. успех имела и выставка в Финляндии, совместно с петербургским художником Сергеем Усиком. В 2003 г.

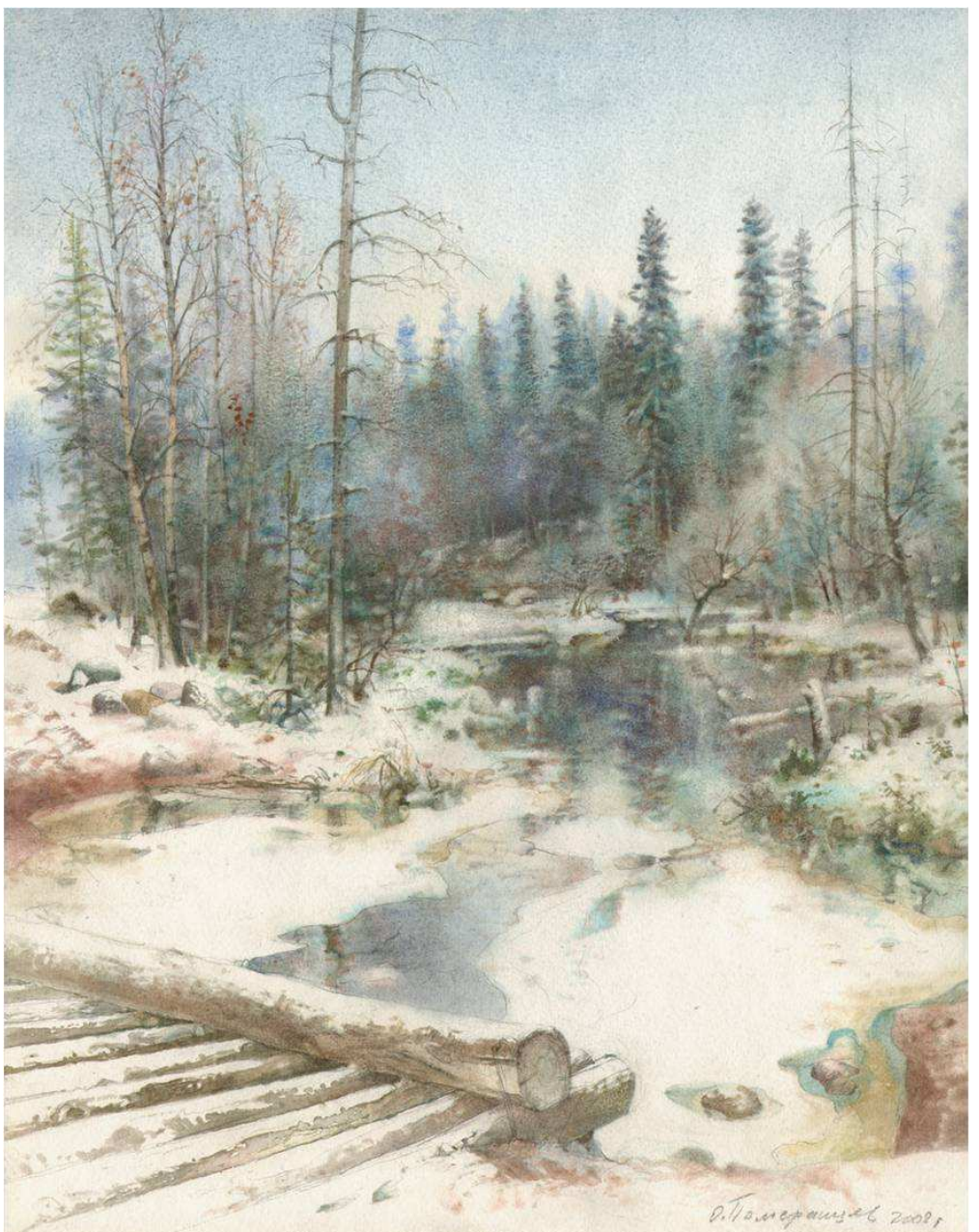

Изобр.8 Померанцев О.И. «Мостик в Кирилловском. Ноябрь. Первый снег», 2002.

30 х 40 см. Бумага, акварель. Собственность В.П. Померанцевой

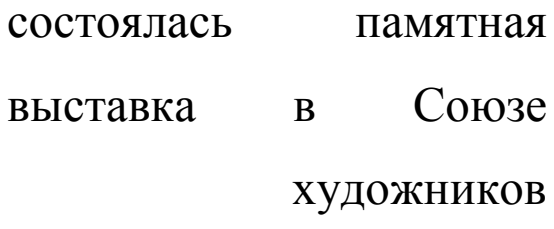

«Акварельный класс», где объединились четыре художника: Владимир Колбасов, Сергей Макаров, Петр Семенов, Олег Померанцев. Олег Игоревич постоянно участвовал в коллективных и персональных выставках как в России, так и за рубежом, был членом Союза архитекторов $\mathrm{CCCP}$, Союза художников России

(секция графики) и членом «Общества акварелистов» Санкт - Петербурга [10].

Кроме того, с 6 до 22 декабря 2013 г. в ВЦ «Эрмитаж-Выборг» проходила выставка «От Выборга до Порвоо» [8], где были представлены работы трех известных петербургских мастеров: О.И.Померанцева, В.Н.Колбасова и Е.В.Дубицкого. А 24 июня 2014 года в петербургской галерее «Мольберт» состоялся вечер памяти художника Олега 
Померанцева с презентацией книги вдовы мастера, Валентины Павловны Померанцевой: «Олег Померанцев. Акварели и рисунки».

«Я уверена, что работы Олега достойны того, чтобы осталась память о его творчестве. Я читала восхищенные отзывы посетителей выставок и это дает мне моральное право опубликовать эту книгу. Журналист Ирина Дудина, не знавшая при жизни

Олега, написала

проникновенные предисловия ко всем частям книги. Я думаю, ей рассказали это сами картины. В книге есть стихи поэта Николая Данилина и не только из-за того, что его связывала с Олегом многолетняя дружба, но и потому что я ощущаю, что они оба говорят на одном языке. В книге можно прочесть теплые слова об Олеге его друзей, художников Сергея Усика и Владимира Колбасова. Олег был прежде всего архитектором и проработал в профессии до последних дней своей жизни. В
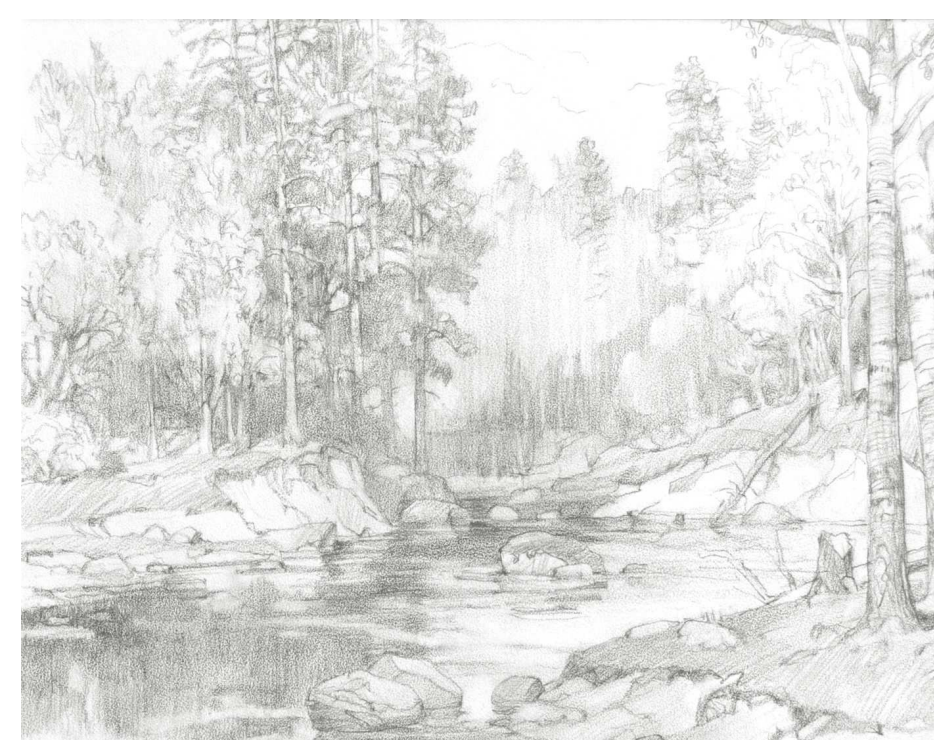

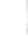


вспоминала об акварелисте В.П.Померанцева на вечере памяти художника [5].

«Олег поехал поступать сначала в Технологический институт, так хотели родители. Я взял на себя смелость и уговорил его, не сообщая родителям, сдать экзамены хотя бы на архитектуру», - отмечал учитель акварелиста, В.Е.Пузанов на вечере памяти художника [5].

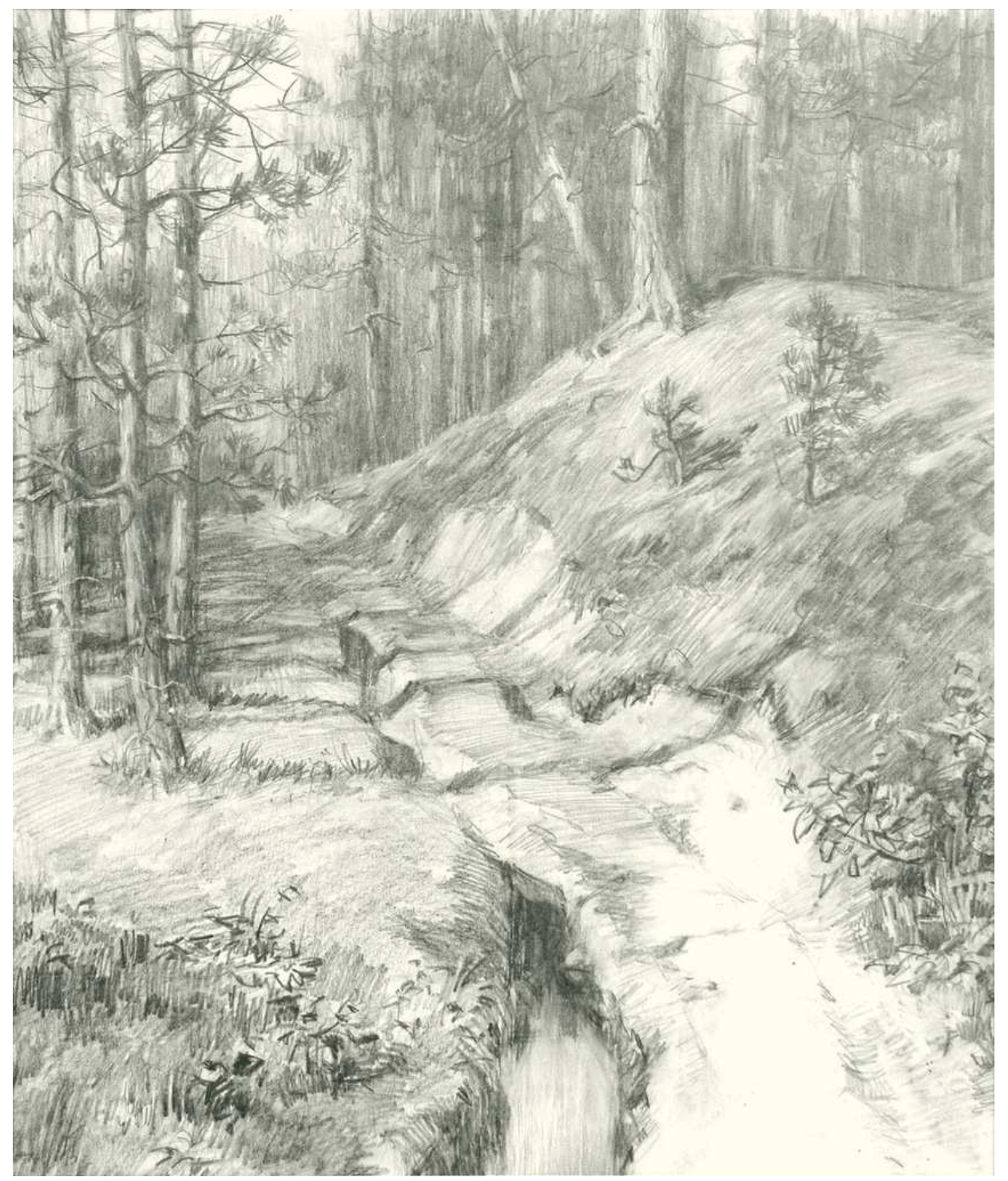

Изобр.10 Померанцев О.И. «Кирилловское» (год создания неизвестен)

37 x 44 см. Бумага, карандаш. Собственность В.П.

Померанцевой 
«Он был изумительным человеком. Он был и художником, рыболовом, и грибником. Живопись была его отдушиной, несмотря на то, что он любил свою профессию. Это тот уникальный случай, когда нет почти ни одной написанной работы на природе. Он очень редко писал на пленэре, это случалось только когда он ездил куда-то с приятелями на машине. Обычно Олег «впитывал» все в себя на природе, а дальше писал дома. У него были разные серии картин: «Уральская», «Времена года»

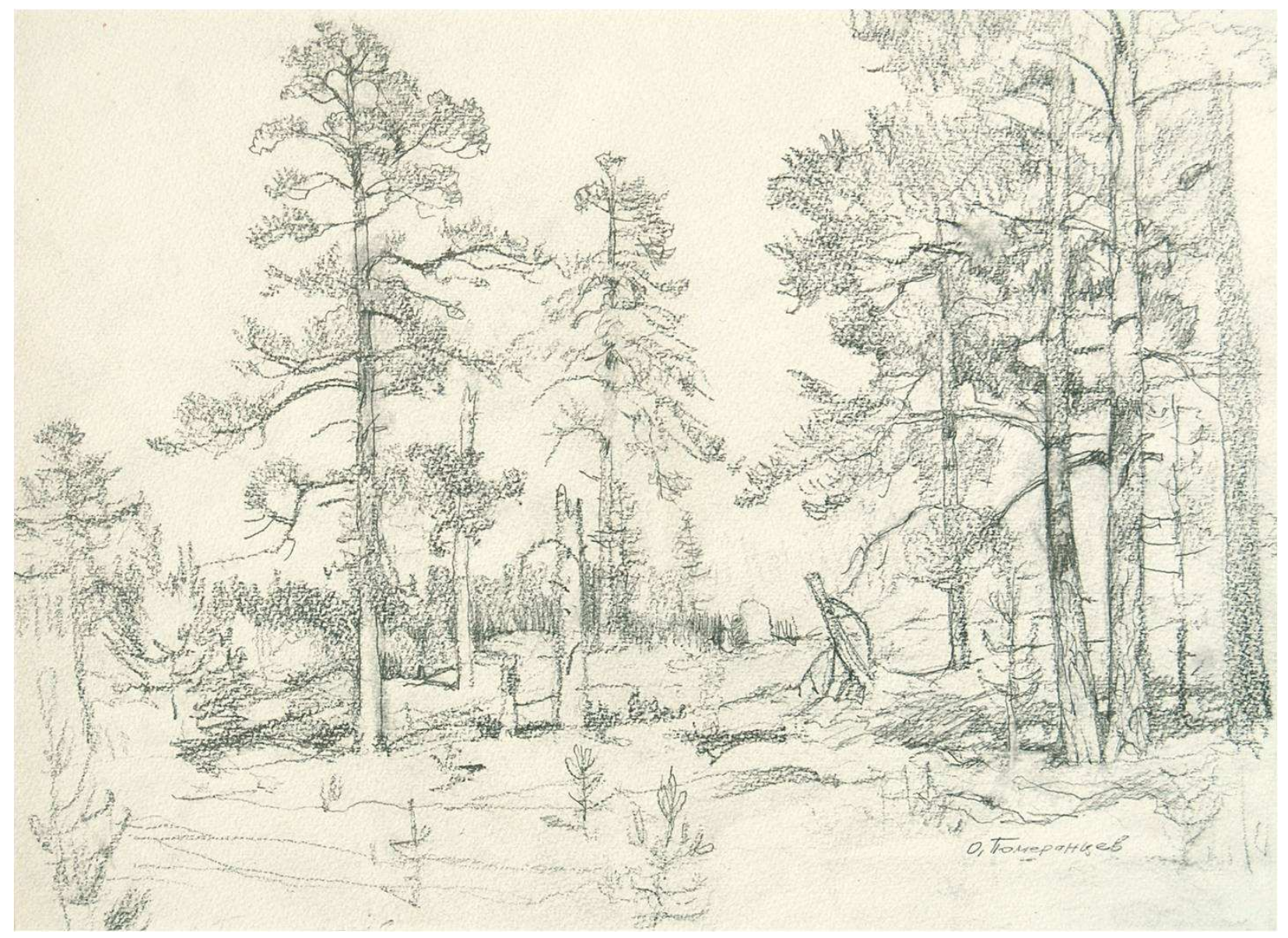

Изобр.11 Померанцев О.И. «Кирилловское» (год создания неизвестен) 42 х 32 см. Бумага, карандаш. Собственность В.П. Померанцевой

(которую все время хотел улучшить, но не успел), «Карельский перешеек». Но больше всего он любил Карелию.

Преподавательской деятельностью он не занимался из-за нехватки времени, а мастер-классы проводились. Но мне кажется то, что человек делал, этому невозможно научить и с этим нужно родиться. Успех был, но не явный, потому что он писал не для чего-то, а просто потому что он не 


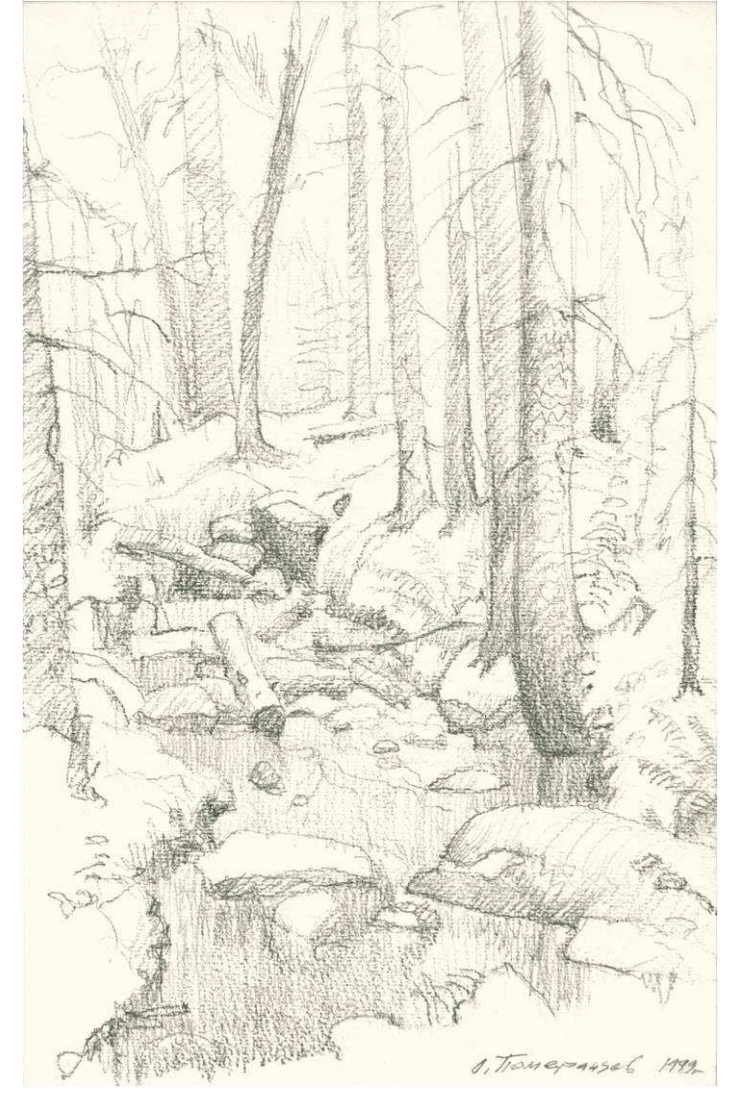

Изобр.12 Померанцев О.И. «Кирилловское», 1999

23 х 36 см. Бумага, карандаш.

Собственность В.П. Померанцевой

задача - подчинить себе акварель, укротить ее. И он не ожидал, что его уровень так высоко оценится, но я интуитивно чувствовала, что его творчество имеет успех. Олег очень любил природу и если вы захотите найти реальные конкретные места, которые изображены в работах с видами Кирилловского, точки с которых были написаны пейзажи, то вы их не найдете, поскольку они не существуют. Это воспоминания. Олег мог из ничего сделать красивое», вспоминала про мужа в своем видео интервью Валентина Павловна Померанцева [6].

Главное место в творчестве Олега Померанцева принадлежит пейзажам, написанным в результате многочисленных поездок в поселок мог не писать. Олег пробовал и масло, но масло у него получалось тоже акварельным. Масло в итоге он забросил, из-за жилищных проблем негде было развернуться. У Олега, на мой взгляд, была сложная внутренняя

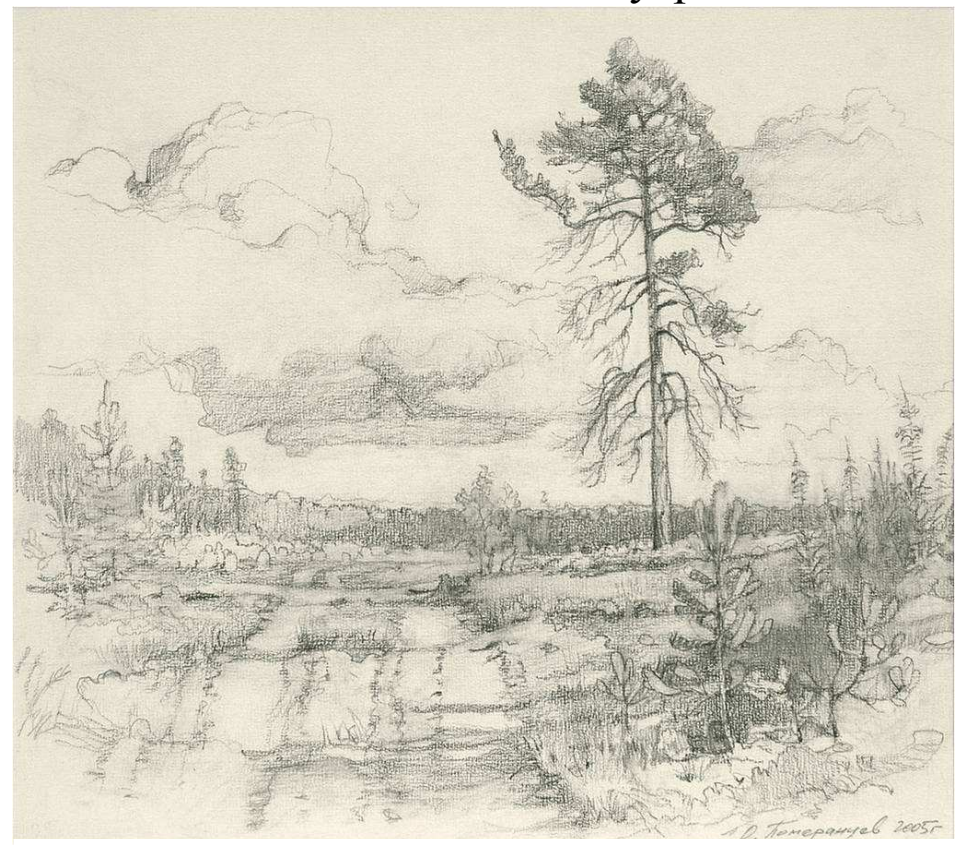

Изобр.13 Померанцев О.И. «Кирилловское», 2005

31 х 27 см. Бумага, карандаш. Собственность В.П. Померанцевой 
Кирилловское Выборгского района, где среди карельских скал растут вековые сосны. С Кирилловским художник ощущал особую неразрывную духовную связь. С особой точностью мастер запечатлел гранитные валуны, величие карельского леса. В пейзажах преобладает, в основном, сдержанная цветовая гамма. Изображая простые, уютные уголки природы, живописец стремился не к фрагментарной трактовке мотива, а к глобальному, предстающему как часть обширного, величественного мира природы. В пейзажах Померанцева можно отметить последовательное освоение живописных достижений великих мастеров русской пейзажной живописи, что проявилось в первую очередь в стремлении к достоверности и высокой одухотворенности в изображении природы Карельского перешейка. Художник был добрым, простым человеком, о чем свидетельствуют и названия его работ, придуманные с большой любовью к северной природе: «Лесная дорога» (2005), «Смолячков ручей. Весенний танец» (2003), «Мостик в Кирилловском. Ноябрь. Первый снег»(2002), «Идем купаться» (2005), «Слепой дождь. Октябрь» (2005), «За грибами. Октябрь» (2009), «Лодочный сарай, Этюд» (2004) .

По словам художника В. Н. Колбасова, Померанцев работал на ненатянутой бумаге (почти

Изобр.14 Померанцев О.И. «Кирилловское» (год создания неизвестен)

27 x 39 см. Бумага, карандаш. Собственность В.П. Померанцевой 
всегда был сталинский гознак, некоторые работы на «немецком торшоне»), по тщательно прорисованному тонким карандашом рисунку. Лист отмачивался в ванне, работа начиналась по - мокрому, послойно, с постепенным набором цвета и периодической промежуточной сушкой листа. Работа велась на чистом листе оргстекла или с использованием тряпичной подкладки. Процесс шел поэтапно, при наборе цвета проводилось моделирование формы. Концовка работы, деталировка велись по - сухому. Использовались приемы выборки цвета кистью, так как белил

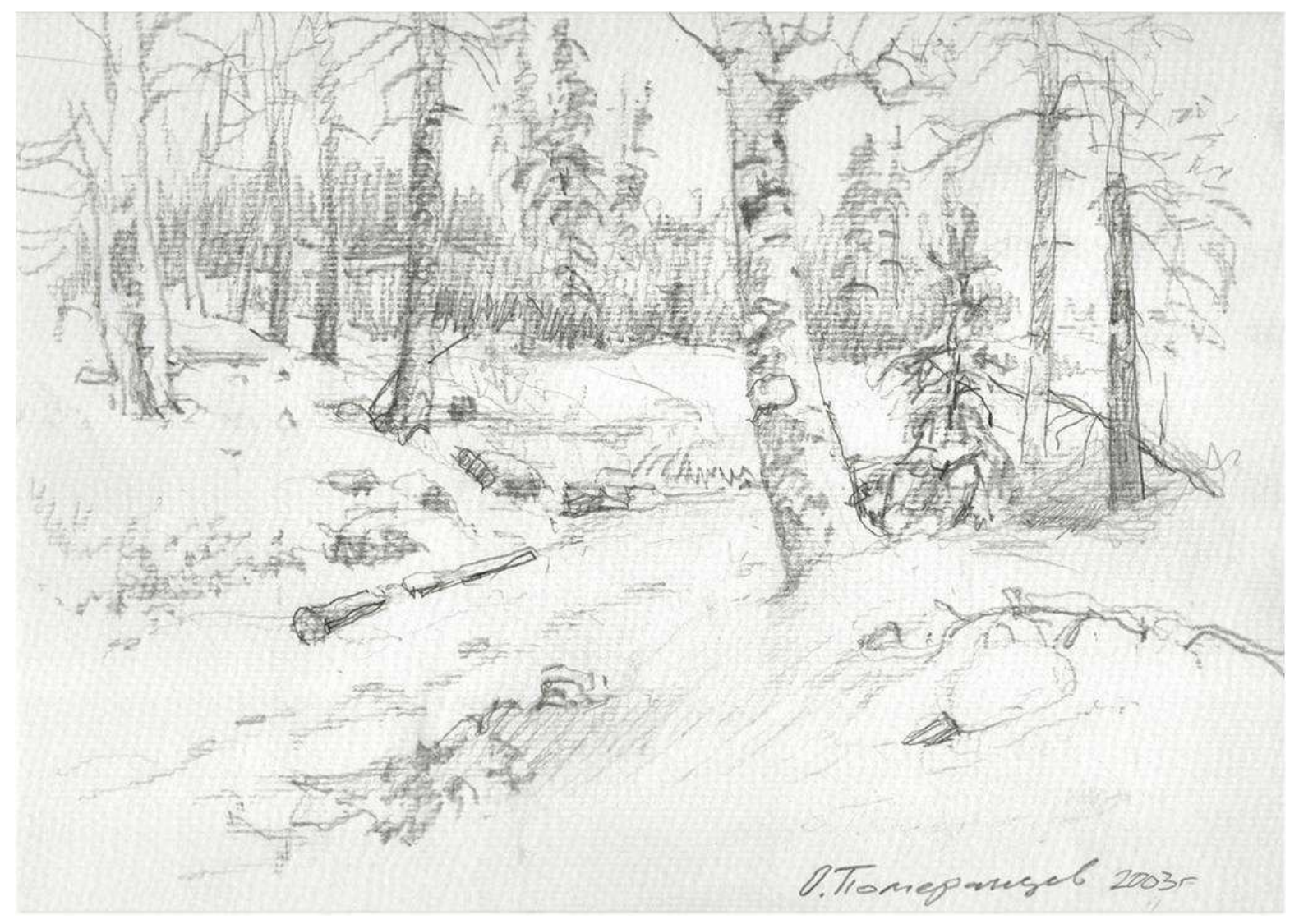

Изобр.15 Померанцев О.И. «Кирилловское», 2003

27 х 19 см. Бумага, карандаш. Собственность В.П. Померанцевой

мастер не использовал категорически. Художник никогда не использовал в акварельных работах и распространенные сегодня дизайнерские изыски: резерв, соль, аммиак, протирание бумагой, монотипия. В его работах нет и акварельного карандаша, темперы. Главный секрет мастерства художника 
- его талантливые руки и необычайная душа. Именно они придают работам неповторимую воздушность, нежность, мягкость и поэтичность [17].

Однажды, вначале 90-х, Олег Померанцев показал Владимиру Колбасову один из своих пейзажей и загадочно улыбаясь, повернул лист

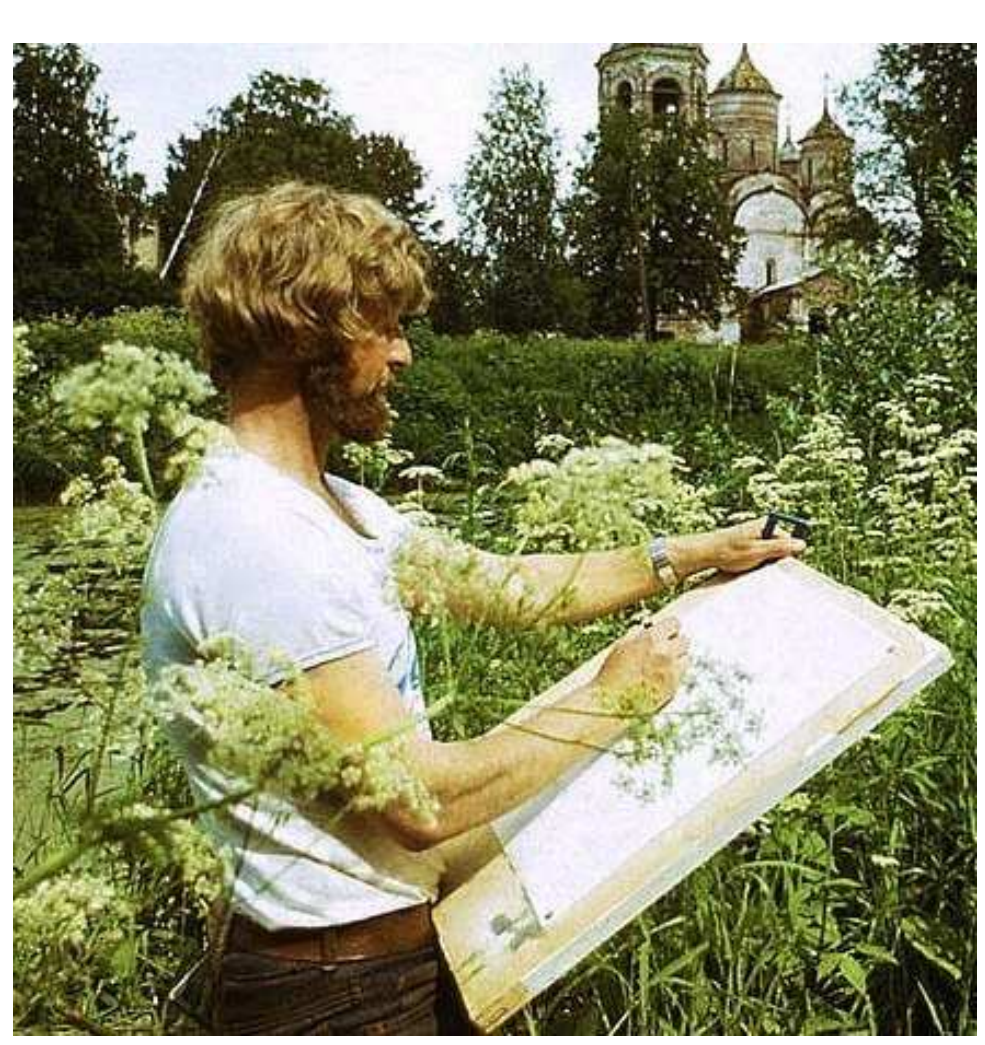

Изобр.16 Акварелист Олег Игоревич Померанцев Источник фото: vk.com/id303714151 тыльной стороной. На обороте листа был фрагмент чужой акварельной монохромной работы по - мокрому, alla prima. Скорее всего, это была серия работ по заказу Художественного фонда. В то время, лист гознака было очень сложно д достать, a огромные работы на гознаке свободно продавались на Невском проспекте, в Лавке Художника, и стоили не дорого. Померанцев, зайдя в лавку, увидел эти запасы, его осенила идея. Он скупил акварели, нарезал на свои форматы и стал писать на них свои работы. Показывая друзьям новую картину, выполненную на этой бумаге, он радостно демонстрировал

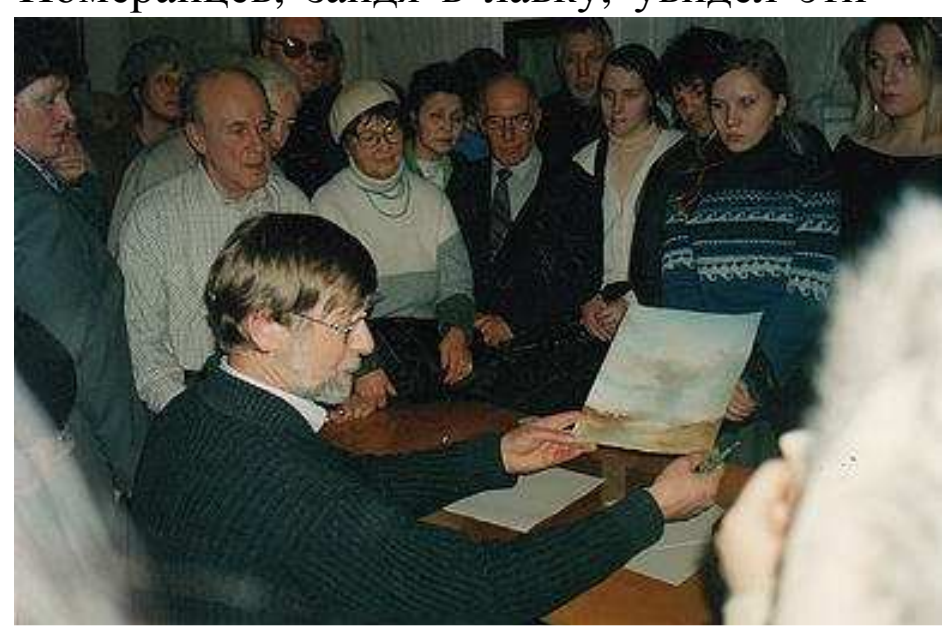

Изобр.17 Мастер-класс акварелиста Олега Игоревича Померанцева, 2011 г. Источник фото: vk.com/id303714151 
оборот листа и благодарил неизвестного художника за такой подарок [17].

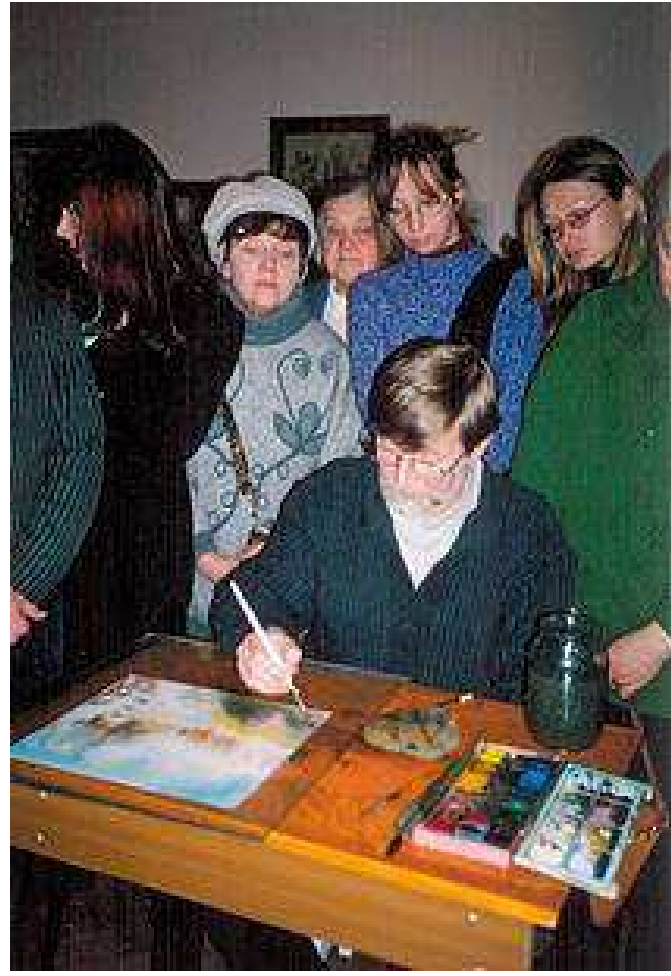

Изобр.18 Мастер-класс акварелиста Олега Игоревича Померанцева, 2011 г. Источник фото: vk.com/id303714151

Остановимся подробно на работах художника с карельскими видами Кирилловского [18]. Поселок расположен на участке Санкт-Петербург - Выборг (88км) и до 1948 года имел финское название Перк-ярви (Perkjärvi) [13]. Проникновенный пейзаж "Июль. Кирилловское" (илл.1) был написан в 1994 году акварельными красками на бумаге. Размер картины небольшой: 31 x 29 см. Квадратный формат позволяет

$\begin{array}{lrr}\text { остановить } & \text { динамику } & \text { действия } \\ \text { композиции } & \text { картины, } \\ \text { композиции } & \text { мягкость, }\end{array}$

Картина состоит из трех планов. На переднем плане расположился

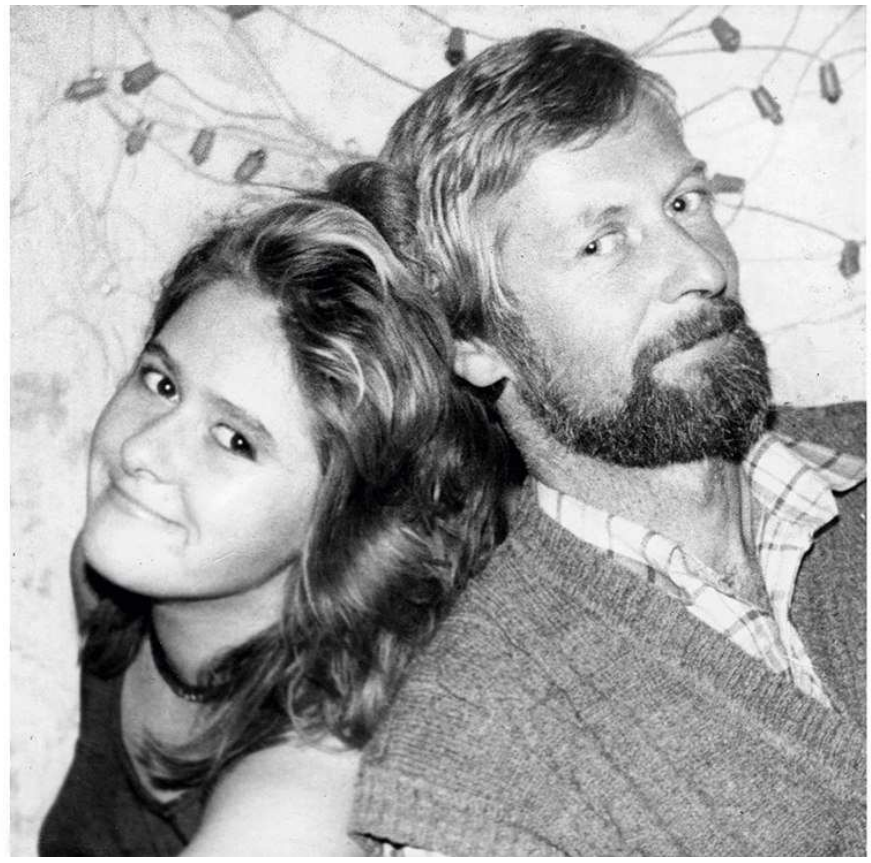

Изобр.19 Олег Игоревич Померанцев с дочерью Анастасией. Источник фото: vk.com/id303714151 
небольшой гранитный валун, обросший мхом. Средний план составляет песчаный холм с высокими соснами, который разрезан посередине небольшим продольным углублением, образовавшимся вследствие размыва почвы. На заднем плане - темный сосновый лес в дымке. Ритм задан техникой нанесения красочного слоя «по-сырому», цветом, светом, пространством. Художник использует контраст холодного и теплого. К примеру, темную листву он пишет холодным болотным темно-зеленым цветом, а при написании песчаных почв использует желтовато- красные теплые цвета. Пушистые облака художник пишет молочным цветом, добавляя фрагментарно темный для изображения туч. Линия горизонта проходит несколько выше геометрической середины картины. Согласно этому, художник предлагает пристальнее взглянуть на сцену среднего плана, возвышающиеся на его фоне объекты. Рассмотрев работу, мы видим, как тонко художник прописывает каждую былинку, небольшие камни, мох, поваленные ветром деревья, пеньки. Поверхность красочного слоя матовая, фактура неровная, шероховатая, за счет использования особой бумаги. Судя по фактуре красочного слоя, мы видим, что использовались несколько методов письма, например «вытягивания» краски. К влажному живописному слою аккуратно прикладывалась отжатая кисть, волос которой впитывал в себя часть пигмента с бумаги, делая тон мазка светлее. Другой способ, использовавшийся в работе - это вымывание краски влажной или отжатой кистью по непросохшему слою. Об этом свидетельствуют некоторые фрагменты картины. В силу того, что художник был большим мастером своего дела, он комбинировал несколько акварельных техник. Способ писать «по-мокрому» позволил художнику получить в работе легкие, прозрачные цветовые оттенки с мягкими переходами. Мастер достиг больших высот в этой технике, что обусловлено постоянным самоконтролем, свободным владением кистью, значительной практикой, позволяющей художнику спрогнозировать 
поведение краски на сырой бумаге и обеспечить достаточный уровень контроля над ее растеканием. Очевидно, что Померанцев имел ясное представление о решении поставленных живописных задач. Во всех работах: «Июль. Кирилловское»(1994), «Кирилловское. Полигон. Июль» (2005), «Мостик в Кирилловском. Ноябрь. Первый снег» (2002), «В Кирилловском»(2001), «Верхний бор. Кирилловское» (2010), художник использует лессировки. Присмотревшись к красочному слою работ, можно увидеть границы мазков, которые придают живописи своеобразную

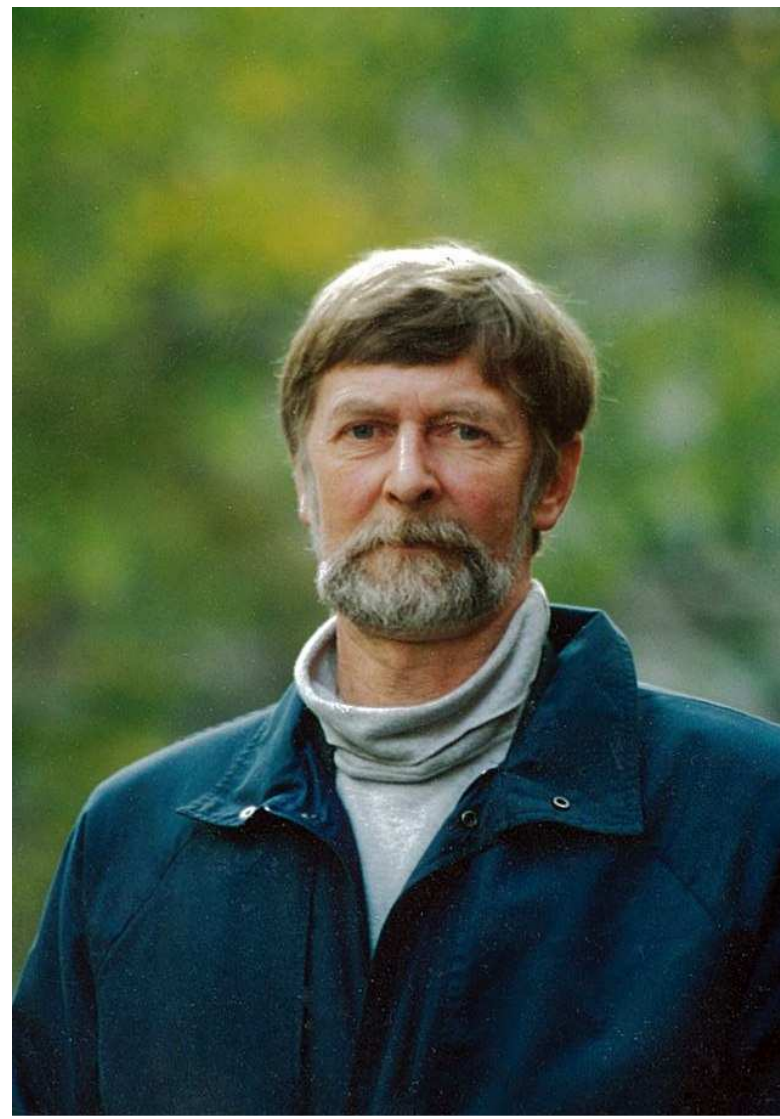

Изобр.20 Олег Игоревич Померанцев (1949-2012) фактуру. Мазки выполнялись художником предельно аккуратно, чтобы не повредить и не размыть уже высохшие живописные участки.

Акварельные работы [14]

Олега Померанцева имеют сходство с масляной живописью, однако, в отличие от нее, они сохраняют прозрачность, звонкость цветов, несмотря на наличие нескольких слоев краски. Лессировки в работах Померанцева помогали ему насытить композицию цветом, глубокими тенями, наполненных красочными рефлексами, мягкими воздушными планами и бесконечными далями. В изображении Карельского перешейка перед художником стояла задача добиться интенсивности цвета, поэтому многослойный прием стоял на первом месте. В панорамной живописи удачно достигнуть цели можно только при помощи лессировки и художник успешно претворил это в жизнь. 
Поскольку художник был независим в вопросах хронологических рамок, работу над картинами он разбивал на несколько сеансов. Например, в работе «Мостик в Кирилловском. Ноябрь. Первый снег»(2002) (илл.2), первый слой краски клался на мокрую бумагу для создания нужной размытости заднего плана, а затем, после высыхания бумаги, наносились последовательно дополнительные слои краски при детальной прорисовке элементов среднего и ближнего планов [9]. Картина имеет небольшой размер: 30 × 40 см. Пейзаж можно разделить на три хорошо выраженных плана. На первом плане расположился бревенчатый мостик, припорошенный снегом, который занимает часть левого нижнего угла. Средний план составляет лесной пруд и деревья, растущие вокруг водоема. На дальнем плане еловый лес в дымке. Композиция линеарная, строящаяся на столкновении пластических линий. Например, на переднем и среднем плане мы можем мысленно нарисовать большой овал, границы которого проходят по кромке пруда. Второй, меньший овал, располагается на среднем плане и имеет более круглую форму. Именно пруд своей необычной формой объединяет все планы картины, углубляет композицию и придает ей воздушную атмосферу. Так же в композиции стоит выделить 2 четкие диагонали: одну на переднем плане, начинающуюся в правом нижнем угле и заканчивающуюся в левом, которая включает в себя деревянный мостик. Вторая диагональ проходит по краю леса на заднем плане. При первом впечатлении от работы создается ощущение дымки. Как на переднем, так и на среднем и заднем планах мы видим занесенные снегом деревянный мостик, землю, пруд, деревья. Художник делает акцент на том, что вода в водоеме еще не замерзла, но местами покрылась тонкой корочкой льда, припорошенного снегом. Именно это помогает зрителю догадаться, что на картине изображен первый снег, заморозки в ноябре, так характерные для этих широт. Ритм мастер создает при помощи техники нанесения красочного слоя, цвета и пространства, которые создают общее 
спокойное настроение картины, настраивают на умиротворение. Художник достигает ощущения холода путем чередования темных и светлых пятен. Поскольку Олег Игоревич никогда не использовал белил, для изображения снега он фрагментарно оставляет незакрашенным белый лист. Цветовые контрасты полотна основаны на смешении холодного и теплого. Линия горизонта на картине высока, небо занимает лишь небольшую часть композиции. Небо здесь выступает как часть композиционного фона, помогающая художнику направить взгляд зрителя к лесу на заднем плане, деревьям и водоему на среднем плане. Общий колорит работы мягкий, что характерно для всего творчества Олега Померанцева. Фактура красочного слоя неровная, шероховатая, за счет использования особой бумаги, поверхность матовая. От полотна веет умиротворением, спокойствием и безмятежностью - так тонко сумел передать Померанцев состояние одного из морозных ноябрьских дней в п.Кирилловское Выборгского района.

Интересны и графические работы художника, выполненные карандашом на бумаге (илл.3;4). По словам вдовы художника, Валентины Павловны Померанцевой, иногда мастер настолько увлекался прорисовкой деталей, что работа уже не годилась под акварель. В акварельных же работах он делал едва заметный рисунок карандашом. Графикой художник специализированно не занимался, и карандашные наброски исключал, как негодные, но супруга художника их сохранила [10]. Удивительно, что графические работы художника, так же как и акварельные работы поражают своей мягкостью, лиричностью. На одной из работ с изображением природы п.Кирилловское нарисована небольшая речка, песчаные берега с небольшими гранитные валунами, высокими соснами (илл.3). Померанцев запечатлел этот сюжет в своей работе очень тонко, кропотливо прорисовывая детали, используя штрихи разной формы, толщины и силы нажима. Отметим, что даже в самом тёмном месте через штриховку просвечивает бумага и именно это даёт общее впечатление 
чистоты, прозрачности работы. Другая графическая работа выполнена более темной штриховкой (илл.4). На картине изображена лесная дорога с глубокими бороздами от колес автотранспорта. По бокам дороги растут мхи, травы, сосны. В этой работе Померанцев смешивает перекрестное штрихование и фрагментарную растушевку, что создает впечатление небольшой небрежности. Можно предположить, что небрежность является следствием общей неаккуратности художника в виду того что во время штрихования рука ездила по бумаге и растирала готовые участки. Но данное предположение представляется нам невозможным в виду того, что художник не только мастерски владел искусством акварели, но и несомненно знал основы графики и мог подложить под руку чистый листочек для того, чтобы избежать растушевки. Подтверждает это и техника, в которой выполнены графические работы. Нам представляется, что несмотря на то, что графикой художник специализированно не занимался, зарисовки отличаются продуманностью деталей. К примеру, штрихи в работе накладывались в соответствии с формой. Например, на рисунке видно, что передний план лежит на горизонтальной плоскости и художник по правилам кропотливо штрихует ее горизонтальными и линиями, а за ним - плоскость вертикальная, которую мастер обозначает вертикальными штрихами. Наиболее внимательно художник на обоих рисунках прорабатывает то, что находится на переднем плане - там самые сильные контрасты светотени. Вдали тональные переходы ровнее, все как будто подернуто дымкой - так он показывает воздушную перспективу.

Романтичные пейзажи Олега Игоревича Померанцева поражают прозрачностью, сложными цветовыми приемами и непередаваемой атмосферой, полной воздуха и света, в них есть глубина, которая завораживает, притягивает, приглашает внутрь. На сегодняшний день работы О. Померанцева представлены в галереях США, Европы и России, а также являются достоянием частных коллекций более 20 стран мира. 
Художник был удивительным, нежным, изысканным, глубоким мастером, а пейзажи Олега Померанцева строго придерживаются традиций классической школы [2]. Неяркие переливы цветов соответствуют гармонии природы, которую изображает художник, композиция выстроена так, что у зрителя возникает эффект присутствия. Пейзажи неброски [3].

«Я не был знаком лично с О.И. Померанцевым. Он мало представлен в интернете. Но с уверенностью могу сказать, что работы этого художника запомнились всем, кто их хоть раз видел. Это касается не технического мастерства, броскости или чего-то, что можно описать словами. В работах Померанцева есть глубина, которая завораживает, притягивает, приглашает внутрь. Это именно то качество тонкости, которое есть у Васильева (прожившего 23 года), но нет у Шишкина. Запомните этого художника! Его творческое наследие может стать прекрасным источником для вдохновения и душевного наполнения», - пишет петербургский акварелист Константин Стерхов, член Санкт-Петербургского Акварельного общества, акварельного общества Финляндии, общества портретистов США [4].

Олег Померанцев - признанный мастер акварельный миниатюры. Введение в научный и художественный оборот имени этого замечательного художника способствует воссозданию полной картины культурного пространства, в котором развивается изобразительное искусство конца XX - начала XXI вв. Исследование творчества Олега Игоревича Померанцева позволит не просто дополнить историю акварельной живописи, но и качественно расширить сложившиеся представления об акварели России в целом.

\section{Список литературы}

1. Акварели Невской Волны. Олег Померанцев [Электронный ресурс]. URL: http://kuzema.my1.ru/photo/oleg_pomerancev/78

2. Акварельный класс // Невское время. - 2004. - 24 января. 
3. Акварель. Продолжая традиции старых мастеров. Олег Померанцев [Электронный ресурс]. URL: http://egen-rosgrafik.blogspot.ru/2013/03/blogpost.html

4. Блог Константина Стерхова. Олег Померанцев [Электронный ресурс]. URL: http://sterkhovblog.waterondvd.ru/oleg-pomerantsev/

5. Вечер памяти художника-акварелиста в «Мольберте» (24.06.2014) [Электронный pecypc]. URL: http://www.youtube.com/watch?v=5s081etamcg

6. Видео интервью «Олег Померанцев. День памяти художника-акварелиста в «Мольберте» В.П.Померанцевой, данное Константину Стерхову для издательства «Планета музыки» [Электронный ресурс]. URL: http://www.youtube.com/watch?v=mBPwTLnB71g

7. Видео интервью в день памяти художника-акварелиста в «Мольберте» В.Е.Пузанова, данное Константину Стерхову для издательства «Планета музыки» [Электронный ресурс]. URL: http://www.youtube.com/watch?v=XV4H_35J4aA

8. Выставка Санкт - Петербургских художников «От Выборга до Порвоо» [Электронный ресурc]. URL: http://erm.vbgcity.ru/node/529

9. Иоханнес Иттен. Искусство цвета - М.: Д.Аронов, 2001.

10. «Любимому мужу и отцу, который всегда с нами». Воспоминания Померанцевой В.П. о супруге.

11. Мартынова А.Г. Возрождение русских классических этнокультурных живописных традиций в творчестве художника-реалиста Олега Игоревича Померанцева (1949-2012). Природа п.Кирилловское в акварелях мастера // Культура России в XXI веке: прошлое в настоящем, настоящее в будущем: Материалы X Всероссийской научно-практической конференции студентов, аспирантов, молодых учёных, 6-7 мая 2014г. СПб., 2014.

12. Мартынова А. От Выборга до Порвоо // Реквизит. - 2013. - 16-22 декабря.

13. Перкъярви - Кирилловское. - СПб.: Остров, 2007. - 176 с.

14. Портал subscribe.ru. Олег Померанцев [Электронный ресурc]. URL: http://subscribe.ru/group/mir-iskusstva-tvorchestva-i-krasotyi/151008/

15. Фундаментальная электронная библиотека. Русская литература и фольклор. Словарь литературных терминов. Ю.Айхенвальд. Реализм и натурализм. [Электронный ресурc]. URL: http://egen-rosgrafik.blogspot.ru/2013/03/blogpost.html

16. Художественная энциклопедия. Реализм. [Электронный ресурc]. URL: http://encdic.com/enc_art/Realizm-1863.html

17. Художник Колбасов В.Н. о близком друге, мастере Померанцеве О.И.

18. Koponen Paavo: Karjalan kirkkokummut. Espoo: Tammi, 1999.

\section{References}

1. Akvareli Nevskoj Volny. Oleg Pomerancev [Jelektronnyj resurs]. URL: http://kuzema.my1.ru/photo/oleg_pomerancev/78

2. Akvarel'nyj klass // Nevskoe vremja. - 2004. - 24 janvarja.

3. Akvarel'. Prodolzhaja tradicii staryh masterov. Oleg Pomerancev [Jelektronnyj resurs]. URL: http://egen-rosgrafik.blogspot.ru/2013/03/blog-post.html

4. Blog Konstantina Sterhova. Oleg Pomerancev [Jelektronnyj resurs]. URL: http://sterkhovblog.waterondvd.ru/oleg-pomerantsev/ 
5. Vecher pamjati hudozhnika-akvarelista v «Mol'berte» (24.06.2014) [Jelektronnyj resurs]. URL: http://www.youtube.com/watch?v=5s081etamcg

6. Video interv'ju «Oleg Pomerancev. Den' pamjati hudozhnika-akvarelista v «Mol'berte» V.P.Pomerancevoj, dannoe Konstantinu Sterhovu dlja izdatel'stva «Planeta muzyki» [Jelektronnyj resurs]. URL: http://www.youtube.com/watch? $\mathrm{v}=\mathrm{mBPwTLnB71g}$

7. Video interv'ju v den' pamjati hudozhnika-akvarelista $\mathrm{v}$ «Mol'berte» V.E.Puzanova, dannoe Konstantinu Sterhovu dlja izdatel'stva «Planeta muzyki» [Jelektronnyj resurs]. URL: http://www.youtube.com/watch?v=XV4H_35J4aA

8. Vystavka Sankt - Peterburgskih hudozhnikov «Ot Vyborga do Porvoo» [Jelektronnyj resurs]. URL: http://erm.vbgcity.ru/node/529

9. Iohannes Itten. Iskusstvo cveta - M.: D.Aronov, 2001.

10. «Ljubimomu muzhu i otcu, kotoryj vsegda s nami». Vospominanija Pomerancevoj V.P. o supruge.

11. Martynova A.G. Vozrozhdenie russkih klassicheskih jetnokul'turnyh zhivopisnyh tradicij v tvorchestve hudozhnika-realista Olega Igorevicha Pomeranceva (19492012). Priroda p.Kirillovskoe v akvareljah mastera // Kul'tura Rossii v XXI veke: proshloe v nastojashhem, nastojashhee v budushhem: Materialy X Vserossijskoj nauchno-prakticheskoj konferencii studentov, aspirantov, molodyh uchjonyh, 6-7 maja 2014g. SPb., 2014.

12. Martynova A. Ot Vyborga do Porvoo // Rekvizit. - 2013. - 16-22 dekabrja.

13. Perk\#jarvi - Kirillovskoe. - SPb.: Ostrov, 2007. - 176 s.

14. Portal subscribe.ru. Oleg Pomerancev [Jelektronnyj resurs]. URL: http://subscribe.ru/group/mir-iskusstva-tvorchestva-i-krasotyi/151008/

15. Fundamental'naja jelektronnaja biblioteka. Russkaja literatura i fol'klor. Slovar' literaturnyh terminov. Ju.Ajhenval'd. Realizm i naturalizm. [Jelektronnyj resurs]. URL: http://egen-rosgrafik.blogspot.ru/2013/03/blog-post.html

16. Hudozhestvennaja jenciklopedija. Realizm. [Jelektronnyj resurs]. URL: http://encdic.com/enc_art/Realizm-1863.html

17. Hudozhnik Kolbasov V.N. o blizkom druge, mastere Pomeranceve O.I.

18. Koponen Paavo: Karjalan kirkkokummut. Espoo: Tammi, 1999. 